
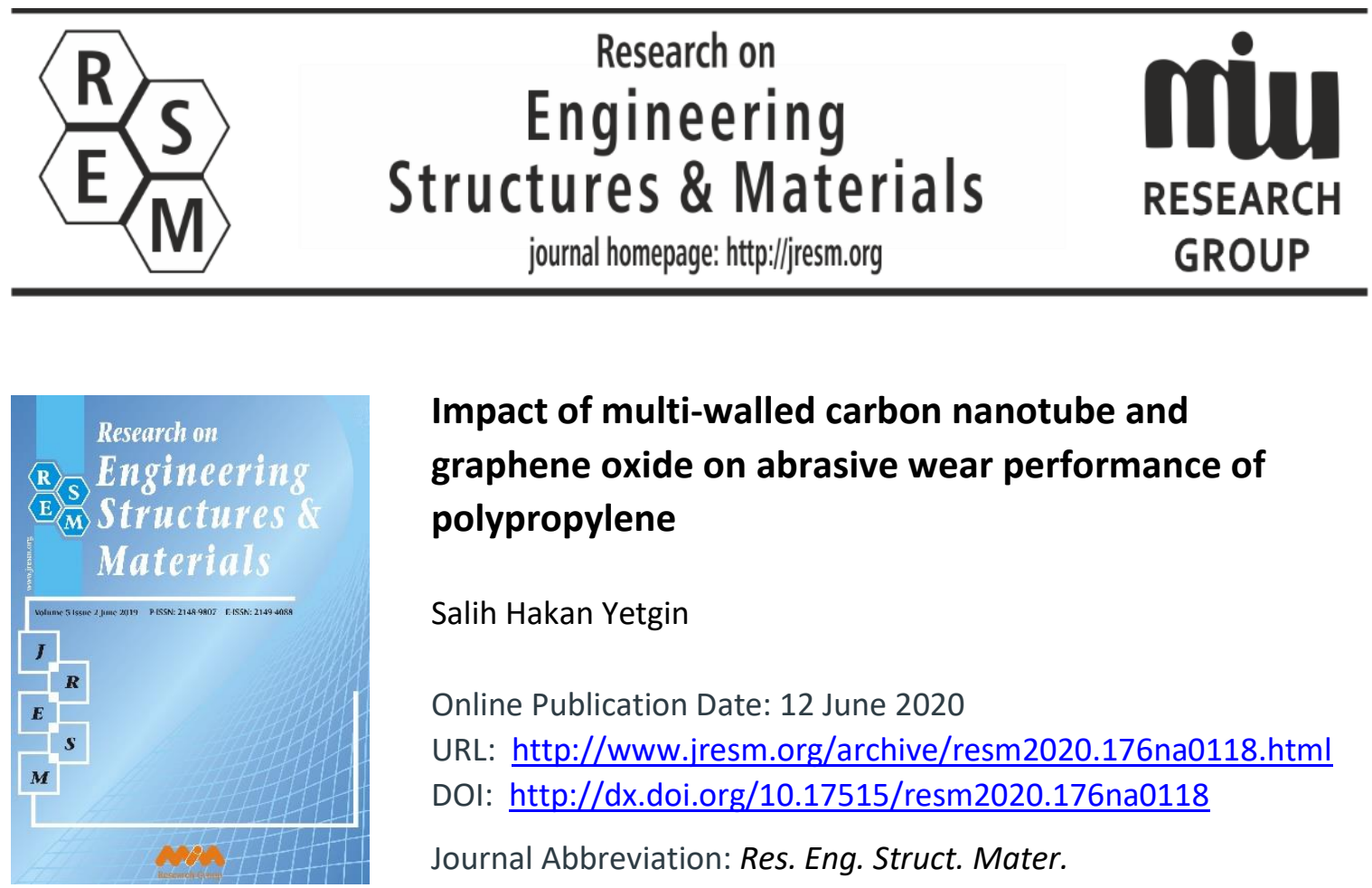

\title{
Impact of multi-walled carbon nanotube and graphene oxide on abrasive wear performance of polypropylene
}

Salih Hakan Yetgin

Online Publication Date: 12 June 2020

URL: http://www.jresm.org/archive/resm2020.176na0118.html

DOI: http://dx.doi.org/10.17515/resm2020.176na0118

Journal Abbreviation: Res. Eng. Struct. Mater.

\section{To cite this article}

Yetgin S H. Impact of multi-walled carbon nanotube and graphene oxide on abrasive wear performance of polypropylene. Res. Eng. Struct. Mater., 2021; 7(1): 157-171.

\section{Disclaimer}

All the opinions and statements expressed in the papers are on the responsibility of author(s) and are not to be regarded as those of the journal of Research on Engineering Structures and Materials (RESM) organization or related parties. The publishers make no warranty, explicit or implied, or make any representation with respect to the contents of any article will be complete or accurate or up to date. The accuracy of any instructions, equations, or other information should be independently verified. The publisher and related parties shall not be liable for any loss, actions, claims, proceedings, demand or costs or damages whatsoever or howsoever caused arising directly or indirectly in connection with use of the information given in the journal or related means.

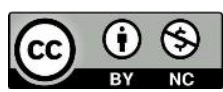

Published articles are freely available to users under the terms of Creative Commons Attribution - NonCommercial 4.0 International Public License, as currently displayed at here (the "CC BY - NC"). 


\title{
Research on Engineering Structures \& Materials
}

journal homepage: http://jresm.org

Research Article

\section{Impact of multi-walled carbon nanotube and graphene oxide on abrasive wear performance of polypropylene}

\author{
Salih Hakan Yetgin
}

Department of Mechanical Engineering, Faculty of Engineering, Tarsus University, Mersin, Turkey

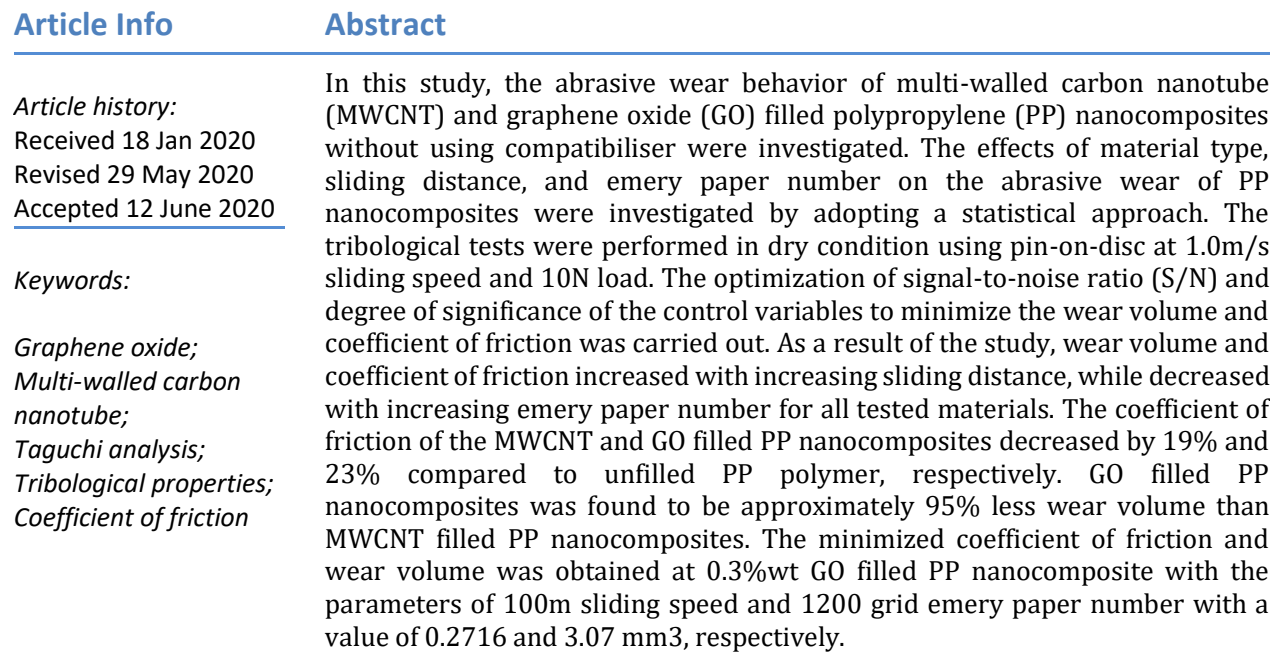

(C) 2021 MIM Research Group. All rights reserved.

\section{Introduction}

Polymer materials are widely used as engineering materials for automotive, electronics, construction, home furnishings, and similar industries because of their low density, easy processability, low cost, and reasonable mechanical strength. However, their usage areas are restricted because of low impact resistance, low service temperature range, and high coefficient of friction (except UHMWPE and PTFE) under dry sliding conditions [1,2]. Traditionally, micro-size fillers and reinforcements have been used to increase the mechanical and tribological properties of the polymer materials. However, in recent years, carbon-based nanoparticles (carbon nanotube and graphene oxide) have become the most important material group for improving the mechanical and the tribological properties of polymers because of their superior thermal, electrical, mechanical properties and large surface area [1, 3-6]. Barretta et al. [7] examined the size-dependent structural response and constitutive behavior of carbon nanotubes (CNTs) by exploiting the modified nonlocal strain gradient elasticity. The structural response of CNTs is modeled by Timoshenko beam and the modified nonlocal strain gradient elasticity theory. Based on the flexural analysis of Timoshenko nano-beam, a novel reduced Euler-Young elastic modulus is introduced for CNTs and calibrated by Molecular Dynamics (MD) simulations results. Mertens and Senthilvelan [1] investigated the mechanical and tribological properties of PP-CNT (carbon nanotube) $(0.5,1.0,3.0$, and $5.0 \mathrm{wt} \%)$ composites prepared using the melt compounding

\footnotetext{
${ }^{*}$ Corresponding author: shyetgin@gmail.com

a orcid.org/0000-0002-6068-9204

DOI: http://dx.doi.org/10.17515/resm2020.176na0118

Res. Eng. Struct. Mat. Vol. 7 Iss. 1 (2021) 157-171
} 
process. As the CNT content increased, the tensile strength and Young's modulus of the PP composites increased. The addition of the CNTs to the PP did not significantly increase the wear resistance of the composite. Shim and Park [8] investigated the viscoelastic properties of the glycidyl methacrylate (GMA) grafted MWCNTs filled PP. Storage modulus, loss modulus, and shear viscosity increased with GMA-MWCNT addition to the PP. Golchin et al. [9] have studied the tribological properties of multi-walled carbon nanotubes (MWCNT) and graphene oxide reinforcement added into the Ultra High Molecular Weight Polyethylene (UHMWPE) polymer. As a result of the study, they have reported that the coefficient of friction and wear ratio values decreased with the addition of multi-walled carbon nanotubes and graphene oxide into the UHMWPE polymer. Liu et al. [10] studied the tribological properties of thermoset polyimide (PI)/graphene oxide nanocomposites. Experimental studies have indicated that the friction and abrasion properties of the polyimide polymer are improved by the addition of graphene oxide. The reason for this is attributed to the uniform transfer film layer formed and the increased load-carrying capacity. Padenko et al. [11] investigated the tribological properties of functionalized graphene reinforced poly-tetra-fluoro-ethylene (PTFE) polymer at $0-4 \%$ by weight. As a result of the study, it has been determined that the friction coefficient decreases with the addition of graphene oxide reinforcement into the PTFE polymer. They determined that the wear rate increased up to $1 \%$ graphene oxide reinforcement addition into the PTFE and decreased after this addition. The reason for this explained by the transfer film layer. They have indicated that they have an important influence on the friction and abrasion properties of the resulting transfer film layer. Bastiurea et al. [12] prepared the graphene oxide and graphite filled polyester composites by using conventional melt-mixing methods to improve the tribological performance of polyester. Hassan et al. [13] investigated the tribological properties of unfilled Low-Density Polyethylene (LDPE), Polyamide-12 (PA12), and graphene nanoplatelets (GNPs) filled polymers by a pin-on-disc tester. Tribological properties showed that LDPE/GNPs and PA12/GNPs nanocomposites have lower coefficients of friction, and wear rates compared with pure LDPE and PA-12. Pan et al. [14] investigated the mechanical and tribological properties of monomer casting (MC) nylon/graphene oxide nanocomposites. The results showed that graphene oxide of very low content had a notable effect on reinforcing the MC nylon matrix. The incorporation of graphene oxide into MC nylon largely reduced wear and friction under dry sliding. The nanocomposites have lower wear rates in comparison with neat MC nylon and the greater the difference, the greater are the loads and the sliding velocities. Shen et al. [15] investigated the effect of the hybrid of multi-wall carbon nanotubes (MWCNTs) and graphene oxide (GO) nanosheets on the tribological performance of epoxy composites. Friction and wear tests against smooth steel showed that the introduction of $0.5 \mathrm{phr}$ MWCNTs into the epoxy matrix increases the friction coefficient and decreases the specific wear rate. When testing the tribological performance of MWCNT/GO hybrids, it is shown that at a high GO amount of $0.5 \mathrm{phr}$, the friction coefficient is decreased below that of the neat matrix whereas the wear rate is increased above that of the neat matrix. At an optimal hybrid formulation, i.e., $0.5 \mathrm{phr}$ MWCNTs and $0.1 \mathrm{phr}$ GO, a further increase in the friction coefficient and a further reduction in the specific wear rate are observed. There have been a lot of investigations related to the test conditions such as normal load, sliding speed, temperature, and environment on the tribological behavior of polymers. In recent years, analytical methods are extensively employed for the optimization and prediction of these test conditions for a wide range of engineering fields. This has the benefit of optimizing several experiments and essential variables. In this view, one of the most effective methods is the Taguchi method. Firojkhan et al. [16] investigated the influence of load, sliding speed, sliding distance, amount of glass fiber on friction coefficient and wear ratio of PTFE composites by using the Taguchi method. Sudheer et al. [17] investigated the effect of test parameters on the wear behavior of potassium-titanate-whiskers (PTW) reinforced epoxy 
composites using the Taguchi method. Sudeepan et al. [18] studied the tribological behavior of micron-sized kaolin filler filled with acrylonitrile-butadiene-styrene (ABS) using Taguchi method. Taguchi design techniques were applied to investigate the significant influence of various operating and design parameters, such as contact load, rotational sliding speed, carbon nanotubes (CNTs) concentration on the tribological properties of UHMWPE nanocomposites by Lawal et al. [19]. The applied normal force was found to be the dominant parameter controlling the wear ratio and friction coefficient. The significance of CNTs concentration on both the coefficient of friction and wear rate closely follows that of the applied load.

In the literature, there are lots of studies that examined wear and friction behaviors by using different types of polymers with filled graphene oxide and MWCNT. In these studies, generally, the effects of the environment (dry, aqueous) and the amount of the GOs and MWCNTs were investigated. According to the authors' knowledge, there are no studies on the tribological properties of graphene oxide and MWCNT filled PP polymers at abrasive conditions. At the same time, in this study, besides the effects of the amount of GO and MWCNT on the friction and wear behavior, the effects of sliding distance and emery paper numbers are also investigated by using Taguchi method.

\section{Experimental Details}

\subsection{Materials}

Commercial Polypropylene (PP) (ExxonMobil Chemical Company, commercial code:PP3374E3) with a specific gravity of $0.9 \mathrm{~g} / \mathrm{cm}^{3}$, a melt flow index (MFI) of $1.3 \mathrm{~g} / 10$ min. (at $230{ }^{\circ} \mathrm{C}$ and $2.16 \mathrm{~kg}$ ) was used as a matrix material. Graphene oxide (G0) was purchased from Nanografen Co (Turkey) with a bulk density, average number of layers and oxygen content of $0.022 \mathrm{~g} / \mathrm{mL}, 27$ and $4.1 \%$, respectively, and multi-walled carbon nanotubes (MWCNT) were purchased from Detsan Company (Turkey). The purity of MWCNTs was declared to be higher than $97 \%$ by the manufacturer. The average outerdiameter and length of MWCNTs are about $10-20 \mathrm{~nm}$ and $10-30 \mu \mathrm{m}$, respectively and its surface area is higher than $200 \mathrm{~m}^{2} / \mathrm{g}$. Figure 1 represents the scanning electron microscope (SEM) images of as-received GO sheets and MWCNT.

\subsection{Fabrications}

Carbon-based nanostructure reinforced nanocomposites were fabricated with a constant filler concentration. MWCNT filled PP nanocomposite specimens were produced with the two-step mixing process. In the first step, PP-MWCNTs pellets were prepared by using a co-rotating twin-screw extruder operated with a screw speed of $350 \mathrm{rpm}$ and barrel temperature of $160-200^{\circ} \mathrm{C}$ from the main feeder to die. In the second step, an injection molding method was utilized to produce nanocomposite laminates. The barrel temperature ranged $215-230^{\circ} \mathrm{C}$ and the mould temperature was kept at $30^{\circ} \mathrm{C}$. A similar route was followed to fabricate GO/PP nanocomposites. Before the production of the $0.3 \%$ wt. GO filled PP nanocomposite, the GO was mixed with distilled water in an ultrasonic mixer to separate the layers. The obtained mixture was mixed with the PP polymer and dried at $100^{\circ} \mathrm{C}$ for 2 hours before the extrusion process. PP nanocomposite granules with graphene oxide were produced in a twin-screw extruder at a temperature range of $185-210^{\circ} \mathrm{C}$. Injection temperatures were determined to be $190-220^{\circ} \mathrm{C}$. The mold temperature is fixed at $30^{\circ} \mathrm{C}$. Figure 2 shows the production scheme of graphene oxide filled PP nanocomposite. 

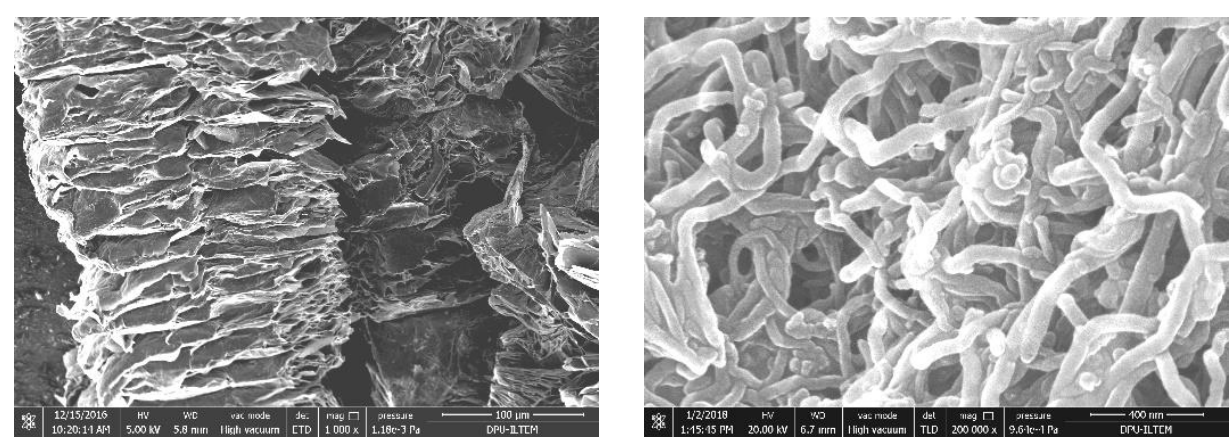

Fig. 1 SEM images of the graphene oxide layers and MWCNT

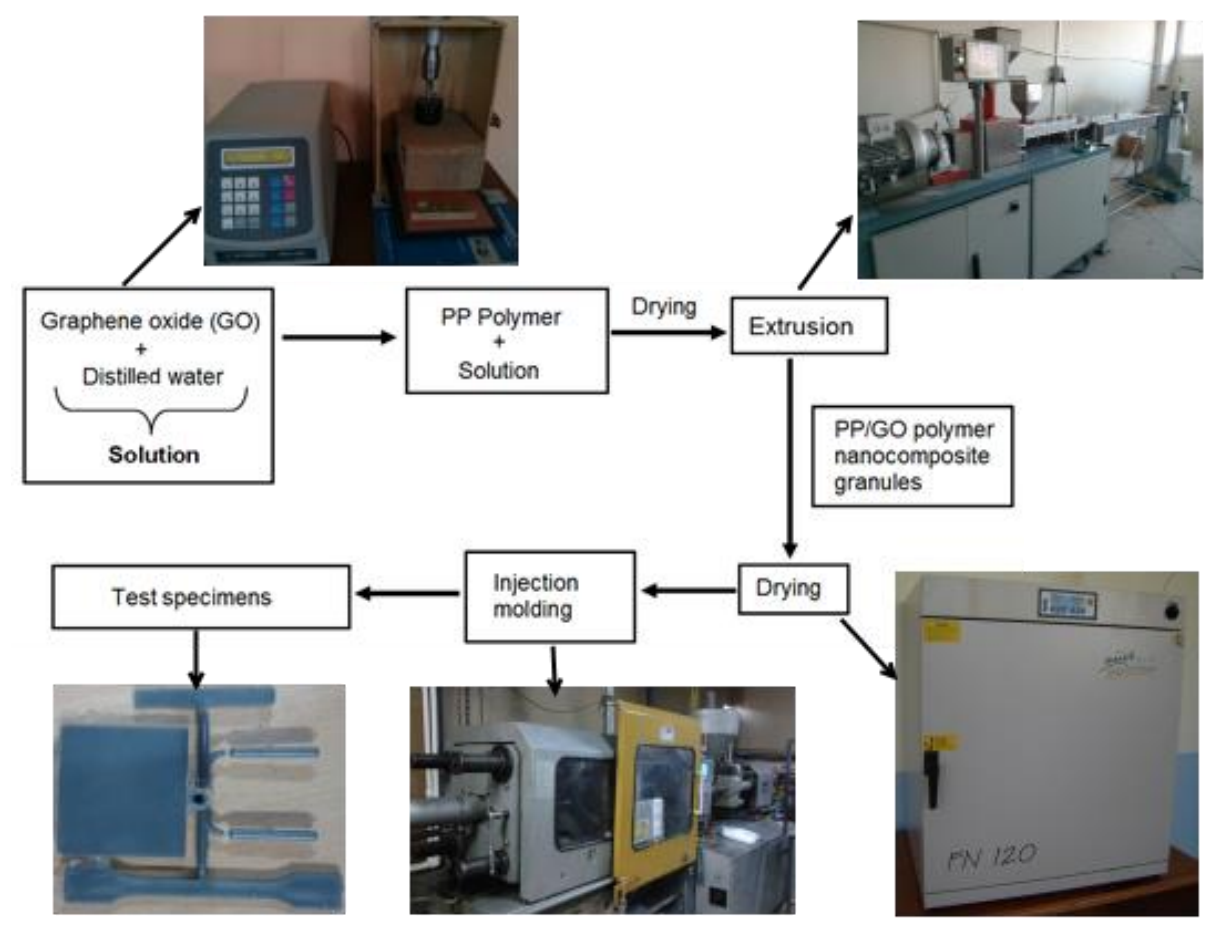

Fig. 2 Production process of graphene oxide filled PP nanocomposite

\subsection{Abrasive wear test}

Abrasive wear tests were performed using a pin-on-disc machine (Figure 3) equipped emery papers with grit grades of 400,800 and 1200 . The emery paper was fixed on the rotating disc surface. Samples with a diameter of $5 \mathrm{~mm}$ and a length of $50 \mathrm{~mm}$ were used for tests. Before each test, samples were cleaned by alcohol and dried in air. Abrasive wear tests were run at the sliding distance of 100,200 and $400 \mathrm{~m}$ and, under $1.0 \mathrm{~m} / \mathrm{s}$ sliding speed and $10 \mathrm{~N}$ load. The wear volume (WV) was computed from the mass loss of the pin. 


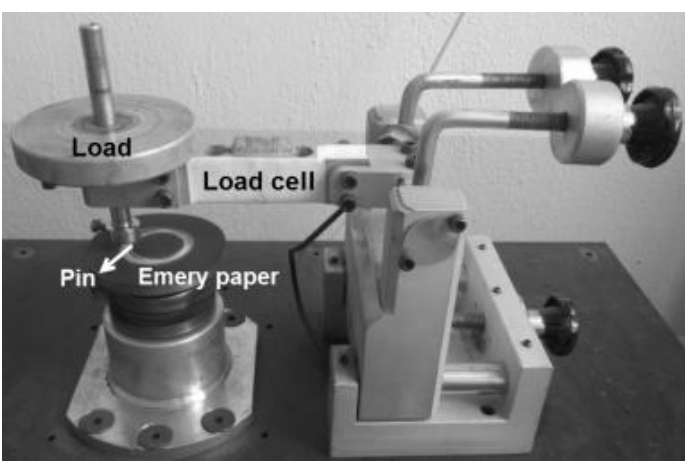

Fig. 3 Wear test device.

\subsection{Experimental Plan and statistical analysis}

In this study, the Taguchi model and statistical analysis process were carried out using MINITAB 17. The most important stage in the design of the experiment lies in the selection of the experimental parameters [20]. Three parameters, namely, material type (A), sliding distance (B) and emery paper number (C) each at three levels, were considered in this study following $\mathrm{L}_{27}\left(3^{3}\right)$ orthogonal array design. The experimental parameters are indicated in Table 1.

Table 1. Experimental parameters

\begin{tabular}{cccc}
\hline Parameters & \multicolumn{3}{c}{ Levels } \\
\cline { 2 - 4 } & I & II & III \\
\hline A: Material type & PP & PP/0.3MWCNT & PP/0.3GO \\
B: Sliding distance, $m$ & 100 & 200 & 400 \\
C: Emery paper number & 400 & 800 & 1200 \\
\hline
\end{tabular}

The results are transformed into a signal-to-noise ratio, which has been used to measure the quality characteristics deviating from the desired values. In the analysis of the $\mathrm{S} / \mathrm{N}$ ratio, there are three categories of quality features: smaller is the best, nominal is the best, and larger is the best. In this work, "smaller is the best" is used to measure the quality characteristics of the coefficient of friction $(\mu)$ and WV. The $S / N$ ratio is calculated from equation 1:

$$
S / N=-10 \times \log \left(\frac{y_{1}{ }^{2}+y_{2}{ }^{2}+\ldots y_{n}{ }^{2}}{n}\right)
$$

Where, ' $n$ ' is the number of observations and ' $y i$ ' is the observed data result of the ith test. Furthermore, a statistical analysis of variance (ANOVA) is performed to identify the statistically significant process parameters. With the S/N and ANOVA analyses, the optimum parameters combination can be predicted to a useful level of accuracy. Finally, a confirmation experiment is performed to verify the optimum parameters. 


\section{Results and Discussion}

\subsection{Control Factors}

The calculated values of the $\mathrm{S} / \mathrm{N}$ ratio were given in Table 2 . The average $\mathrm{S} / \mathrm{N}$ ratio for the coefficient of friction $(\mu)$ and wear volume (WV) was obtained as $9.42 \mathrm{~dB}$ and $-16.81 \mathrm{~dB}$ from Table 2. The main effects plots of $\mathrm{S} / \mathrm{N}$ for $\mu$ and $\mathrm{WV}$ were given in Figure 4-a and 4-b. Generally, these figures show that $\mathrm{S} / \mathrm{N}$ ratio values differ with material type, sliding distance, and emery paper number values. The optimal process conditions of experimental parameters could be easily decided from these graphs. The highest $\mathrm{S} / \mathrm{N}$ value is represented that the optimal level of the process factors. It could be seen in Fig. 4-a and 4$b$ that the optimized process condition for PP nanocomposites became $A_{3} B_{1} C_{3}$ for main control factors as for PP/0.3GO with the sliding distance of $100 \mathrm{~m}$, and the emery paper number of 1200. The friction coefficient of the PP and its composites were increased with the increase in sliding distance and decreased with the increase in the emery paper number. Minimum $\mu$ values were obtained with the material type of PP/0.3GO. It is known that graphene, as filler with high strength and high thermal conductivity, can improve the load- carrying capacity and transmission of frictional heat of the composites [11]. Rafiee et al. $[21,22]$ stated that the graphene structure provides better stress transfer than CNT during the applied load. Padenko [23] also explained that the reduction in the coefficient of friction is due to the self-lubrication behaviors of graphene oxide and the formation of the transfer film on the disc surface under dry sliding conditions. Polymer nanocomposites have superior friction properties because graphene oxide has small dimensions, thin layer structure and excellent self-lubrication properties. This plays an important role during friction tests in reducing the shear force and in the formation and preservation of low friction [24]. The WV of the PP and its composites were decreased with the increase in the emery paper number and increased with the increasing sliding distance. Minimum WV values were obtained with the material type of the PP/0.3GO because of the GO can be readily released from the $P P$ to form a third-body transfer film, which leads to reduce the direct contact between the PP and emery paper counterface. The graphene could work as a solid lubricant material between the two contacted surfaces and prevent direct contact between them, thereby reduce the $\mu$ and increase the WV [4].

Analysis of the impact of each parameter on the coefficient of friction and wear volume was carried out with the $\mathrm{S} / \mathrm{N}$ response table. The control factors were classified with different values. The response for the coefficient of friction and wear volume of the PP nanocomposite materials are also presented in Table 3. It can be seen that the strongest effect was obtained as factor material type for $\mu$ and sliding distance for $\mathrm{WV}$ in these tables.

Table 2. Experimental results and $\mathrm{S} / \mathrm{N}$ ratios

\begin{tabular}{|c|c|c|c|c|c|c|}
\hline \multirow[t]{2}{*}{ Material type } & \multirow{2}{*}{$\begin{array}{c}\text { Sliding } \\
\text { distance, m }\end{array}$} & \multirow{2}{*}{$\begin{array}{c}\text { Emery } \\
\text { paper } \\
\text { number }\end{array}$} & \multicolumn{2}{|c|}{$\begin{array}{l}\text { Coefficient of } \\
\text { friction, } \mu\end{array}$} & \multicolumn{2}{|c|}{$\begin{array}{l}\text { Wear volume } \\
\qquad\left(\mathrm{mm}^{3}\right)\end{array}$} \\
\hline & & & Measured & $S / N$ & Measured & $\mathbf{S} / \mathbf{N}$ \\
\hline PP & 100 & 400 & 0,3861 & 8,2660 & 5,52 & $\begin{array}{c}- \\
14,8454\end{array}$ \\
\hline PP & 100 & 800 & 0,3509 & 9,0963 & 4,62 & $\begin{array}{c}- \\
13,2972\end{array}$ \\
\hline PP & 100 & 1200 & 0,3344 & 9,5147 & 3,72 & $\begin{array}{c}- \\
11,4118\end{array}$ \\
\hline PP & 200 & 400 & 0,3921 & 8,1321 & 8,68 & $\begin{array}{c}- \\
18,7713\end{array}$ \\
\hline PP & 200 & 800 & 0,3691 & 8,6571 & 7,33 & $\begin{array}{c}- \\
17,2998\end{array}$ \\
\hline
\end{tabular}




\begin{tabular}{|c|c|c|c|c|c|c|}
\hline PP & 200 & 1200 & 0,3431 & 9,2916 & 6,09 & $\begin{array}{c}- \\
15,6894\end{array}$ \\
\hline PP & 400 & 400 & 0,4132 & 7,6768 & 1,03 & $\begin{array}{c}- \\
20,2224\end{array}$ \\
\hline PP & 400 & 800 & 0,3951 & 8,0659 & 9,81 & $\begin{array}{c}- \\
19.8319\end{array}$ \\
\hline PP & 400 & 1200 & 0,3693 & 8,6524 & 8,12 & $\begin{array}{c}- \\
18,1882\end{array}$ \\
\hline PP/0.3MWCNT & 100 & 400 & 0,3365 & 9,4603 & 9,10 & $\begin{array}{c}- \\
19,1819\end{array}$ \\
\hline PP/0.3MWCNT & 100 & 800 & 0,3061 & 10,2827 & 6,97 & $\begin{array}{c}- \\
16,8600\end{array}$ \\
\hline PP/0.3MWCNT & 100 & 1200 & 0,2804 & 11,0444 & 4,94 & $\begin{array}{c}- \\
13,8813\end{array}$ \\
\hline PP/0.3MWCNT & 200 & 400 & 0,3526 & 9,0544 & 1,08 & $\begin{array}{c}- \\
20,6576\end{array}$ \\
\hline PP/0.3MWCNT & 200 & 800 & 0,3343 & 9,5173 & 8,54 & $\begin{array}{c}- \\
18,6285\end{array}$ \\
\hline PP/0.3MWCNT & 200 & 1200 & 0,3041 & 10,3397 & 7,42 & $\begin{array}{c}- \\
17,4031\end{array}$ \\
\hline PP/0.3MWCNT & 400 & 400 & 0,3841 & 8,3111 & 1,30 & $\begin{array}{c}- \\
22,3014\end{array}$ \\
\hline PP/0.3MWCNT & 400 & 800 & 0,3605 & 8,8619 & 1,13 & $\begin{array}{c}- \\
21,0986\end{array}$ \\
\hline PP/0.3MWCNT & 400 & 1200 & 0,3335 & 9,5381 & 9,10 & $\begin{array}{c}- \\
19,1819\end{array}$ \\
\hline $\mathrm{PP} / 0.3 \mathrm{GO}$ & 100 & 400 & 0,3153 & 10,0255 & 4,66 & $\begin{array}{c}- \\
13,3660\end{array}$ \\
\hline $\mathrm{PP} / 0.3 \mathrm{GO}$ & 100 & 800 & 0,2955 & 10,5889 & 3,86 & $\begin{array}{c}- \\
11,7399\end{array}$ \\
\hline $\mathrm{PP} / 0.3 \mathrm{GO}$ & 100 & 1200 & 0,2716 & 11,3214 & 3,07 & $-9,7376$ \\
\hline $\mathrm{PP} / 0.3 \mathrm{GO}$ & 200 & 400 & 0,3421 & 9,3169 & 7,84 & $\begin{array}{c}- \\
17,8873\end{array}$ \\
\hline $\mathrm{PP} / 0.3 \mathrm{GO}$ & 200 & 800 & 0,3175 & 9,9651 & 6,02 & $\begin{array}{c}- \\
15,5959\end{array}$ \\
\hline $\mathrm{PP} / 0.3 \mathrm{GO}$ & 200 & 1200 & 0,2943 & 10,6242 & 5,57 & $\begin{array}{c}- \\
14,9143\end{array}$ \\
\hline $\mathrm{PP} / 0.3 \mathrm{GO}$ & 400 & 400 & 0,3621 & 8,8234 & 8,86 & $\begin{array}{c}- \\
18,9522\end{array}$ \\
\hline $\mathrm{PP} / 0.3 \mathrm{GO}$ & 400 & 800 & 0,3245 & 9,7757 & 7,05 & $\begin{array}{c}- \\
16,9582\end{array}$ \\
\hline $\mathrm{PP} / 0.3 \mathrm{GO}$ & 400 & 1200 & 0,3089 & 10,2036 & 6,48 & $\begin{array}{c}- \\
16,2278\end{array}$ \\
\hline
\end{tabular}


Table 3. Response table for $\mathrm{S} / \mathrm{N}$ ratios (dB) and means.

\begin{tabular}{|c|c|c|c|c|c|c|c|c|}
\hline \multirow{2}{*}{$\begin{array}{l}\text { Control } \\
\text { Factors }\end{array}$} & \multicolumn{4}{|c|}{ Coefficient of friction, $\mu$} & \multicolumn{4}{|c|}{ Wear volume, $\mathbf{m m}^{3}$} \\
\hline & 1 & 2 & 3 & Delta & 1 & 2 & 3 & Delta \\
\hline \multicolumn{9}{|c|}{$\mathrm{S} / \mathrm{N}$ ratio $(\mathrm{dB})$} \\
\hline $\begin{array}{l}\text { Material } \\
\text { type }\end{array}$ & 8.595 & 9.601 & 10.072 & $1.477^{1}$ & $\begin{array}{c}- \\
16.62\end{array}$ & $\begin{array}{c}- \\
18.80\end{array}$ & $\begin{array}{c}- \\
15.04\end{array}$ & $3.76^{2}$ \\
\hline $\begin{array}{c}\text { Sliding } \\
\text { distance }\end{array}$ & 9.956 & 9.433 & 8.879 & $1.077^{3}$ & $\begin{array}{c}- \\
13.81\end{array}$ & $\begin{array}{c}- \\
17.43\end{array}$ & $\begin{array}{c}- \\
19.22\end{array}$ & $5.40^{1}$ \\
\hline $\begin{array}{c}\text { Emery } \\
\text { paper } \\
\text { number }\end{array}$ & 8.785 & 9.423 & 10.059 & $1.274^{2}$ & $\begin{array}{c}- \\
18.47\end{array}$ & $\begin{array}{c}- \\
16.81\end{array}$ & $\begin{array}{c}- \\
15.18\end{array}$ & $3.28^{3}$ \\
\hline \multicolumn{9}{|l|}{ Means } \\
\hline $\begin{array}{l}\text { Material } \\
\text { type }\end{array}$ & 0.3726 & 0.3325 & 0.3146 & $0.0579^{1}$ & 7.128 & 9.026 & 5.934 & $3.092^{2}$ \\
\hline $\begin{array}{c}\text { Sliding } \\
\text { distance }\end{array}$ & 0.3196 & 0.3388 & 0.3612 & $0.0416^{3}$ & 5.163 & 7.586 & 9.339 & $4.176^{1}$ \\
\hline $\begin{array}{c}\text { Emery } \\
\text { paper } \\
\text { number }\end{array}$ & 0.3649 & 0.3393 & 0.3155 & $0.0494^{2}$ & 8.750 & 7.283 & 6.056 & $2.694^{3}$ \\
\hline
\end{tabular}
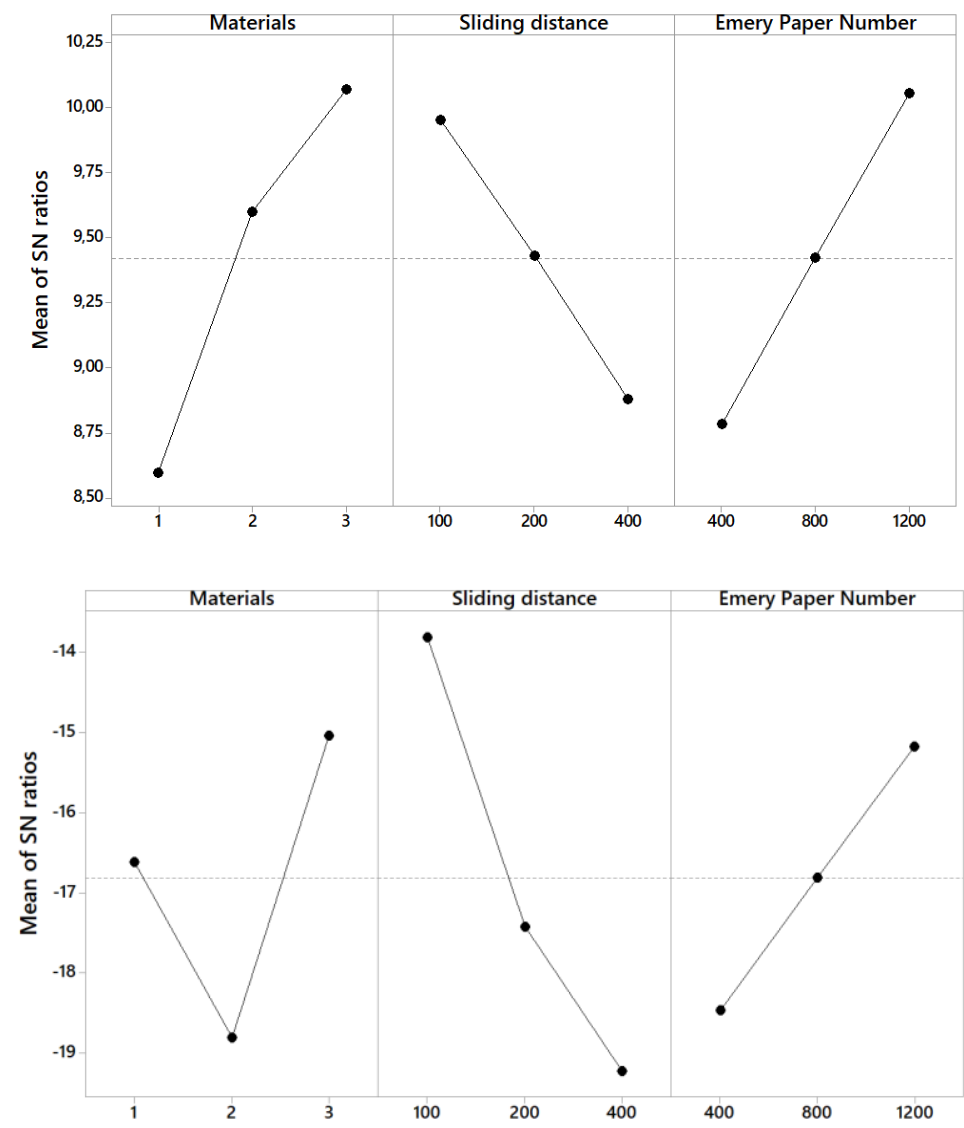

Fig. 4 Main effect plots, a) $\mu$, b) WV. 
The interaction effect plots were given in Fig. 5. The relationship between experimental parameters and levels and results can be derived from the interaction plots. It is well known that interactions do not occur when the lines on the interaction plots are parallel and strong interactions occur between parameters when the lines cross [25]. The coefficient of friction and wear volume decreases with the increasing emery paper number. The coefficient of friction for PP polymer decreased by 15\%, for PP/0.3MWCNT polymer by $20 \%$ and for PP/0.3G0 polymer by $16 \%$ with increasing emery paper number. Also, the coefficient of friction and wear volume increased with increasing sliding distance. The coefficient of friction increased by $7 \%$ for PP polymer, $14.1 \%$ for PP $/ 0.3 \mathrm{MWCNT}$ polymer and $14.8 \%$ for PP/0.3GO polymer with increasing the sliding distance from 400 to 1200. Similar results are obtained by Suresha et al. [26]. Suresha et al. [26] stated that the wear volume tends to increase near linearly with increasing abrading distance and strongly depends on the grit size of abrasive paper. The lowest wear volume was obtained for $\mathrm{PP} / 0.3 \mathrm{GO}$ while the highest wear volume was obtained for PP/0.3MWCNT. The minimum wear volume of PP/0.3GO composite is nearly $25 \%$ and $40 \%$ less than that of unfilled PP polymer and PP/0.3MWCNT at the same test conditions, respectively.

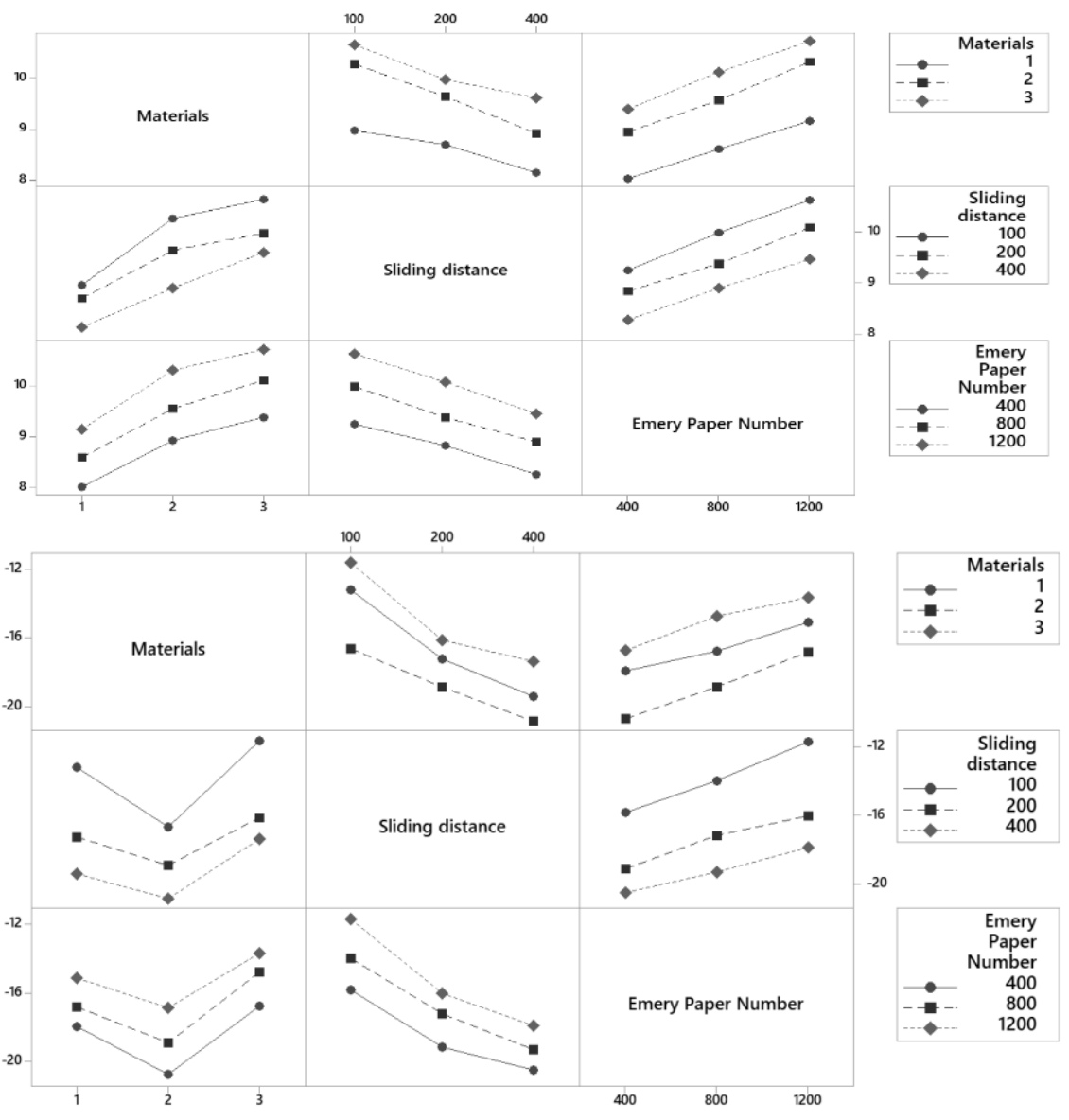

Fig. 5 Interaction effect plots; a) $\mu$, b) WV. 


\subsection{Analysis of variance (ANOVA)}

ANOVA is a method most widely used and aims at determining significant parameters on response and measuring their individual effects. The ratio of percentage (PCR \%) of experimental parameters is used to determining the corresponding effect on the results. When ' $\mathrm{P}$ ' is less than the ' $5 \%$ ' column value the assigned factor is statistically and significant. Table 4 presents the ANOVA for the $\mu$ and WV.

One can observe from Table 4 that material type has greater statistically influence of $44.84 \%$, emery paper number has an influence of $31.02 \%$ and sliding distance has an influence of $22.01 \%$ on $\mu$. However, the interaction between material type*sliding distance $(\mathrm{P}=0.035)$, material type*emery paper number $(\mathrm{P}=0.775)$, and lastly sliding distance*emery paper number $(\mathrm{P}=0.793)$ show less significance of contribution on the coefficient of friction. In Table 4, when PCR values of the WV were evaluated, the material types $(\mathrm{PCR}=27.01 \%)$, the sliding distance (PCR=48.84\%), emery paper number (PCR=20.21\%) influence on the WV. The interactions material type*sliding distance, material type*emery paper number and sliding distance*emery paper number were for WV PCR $=1.24 \%, \mathrm{PCR}=2.00 \%, \mathrm{PCR}=0.24 \%$, respectively. These interactions are very minimum and can be neglected. The error was a small value of 0.46 . This result was supported successful of the ANOVA.

Table 4. ANOVA results of means for $\mu$ and WV.

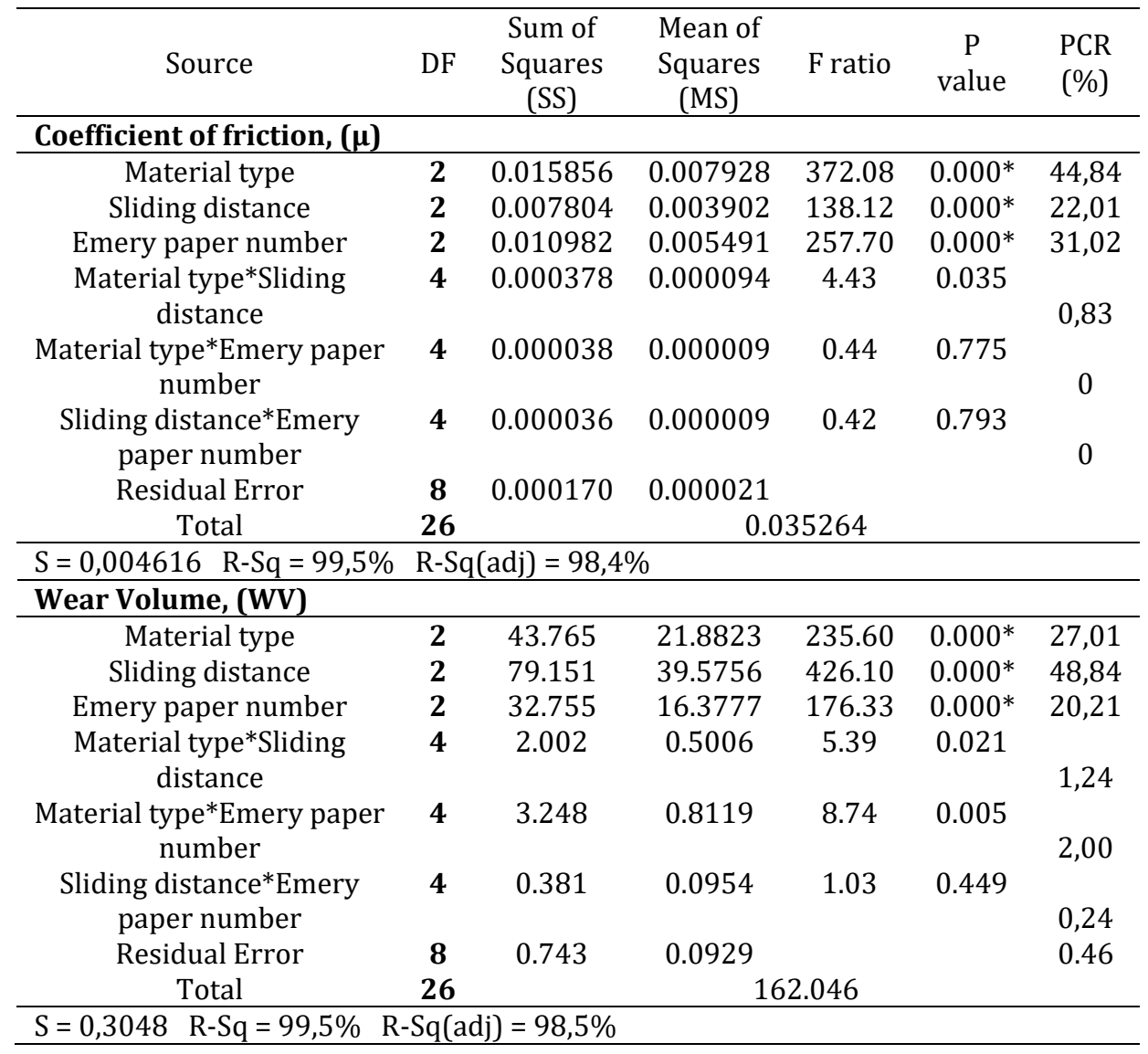

\footnotetext{
$*$ is significant parameter at $95 \%$ confidence level.
} 


\subsection{Confirmation tests}

The final step of the Taguchi method is to perform a confirmatory experiment for examining the quality characteristic. The two approaches to confirmation are multiplied. In the first one, $\mathrm{S} / \mathrm{N}$ values are compared with the second one, and confirmation is made according to Means values. In this study, confirmation tests will be evaluated considering Means values. The confirmation test was performed with an optimized factor set of factors A3B1C3 to predict the $\mu$ and WV. The estimated means for the $\mu$ and $\mathrm{WV}$ can be calculated from equation 2, where, $\mathrm{T}$ the overall experimental average, and $\mathrm{A} 3, \mathrm{~B} 1$, and $\mathrm{C} 3$ is the mean response for the factors:

$$
\begin{aligned}
& \mu=T+(A 3-T)+(B 1-T)+(C 3-T) \\
& \mu=0.27 \\
& W V=2.433
\end{aligned}
$$

A confidence interval for the predicted mean of the confirmation run can be calculated using equation 3 and 4 [27];

$$
C I=\sqrt{F_{\alpha ; 1 ; v 2} \times V_{e} \times\left(\frac{1}{n_{e f f}}+\frac{1}{r}\right)}
$$

where $\mathrm{F}_{\alpha ; 1 ; v 2}=$ The $\mathrm{F}$ value from the $\mathrm{F}$ Table at a required confidence level at DOF 1 and error DOF v2, $V_{e}$ is the variance of the error term, $r$ is the replication number, $n_{e f f}$ is the number of valid measurement results [28];

$$
n_{e f f}=\frac{T_{d e n}}{1+d o f}
$$

Where; $T_{d e n}$ is the total number of the experiment, dof is the total degree of freedom of the factors used for prediction [29]. The confidence interval for the $\mu$ and WV calculated from equation 3 and 4, and the results are given in Table 5. Furthermore, a comparison of the results of the confirmation test which was performed according to the optimum levels of the variables was given in Table 5 . It can be seen from Table 5, the result values of the conducted confirmation test for the responses are obtained in the confidence interval with

\begin{tabular}{|c|c|c|c|c|c|c|c|c|}
\hline \multirow[b]{2}{*}{ Response } & \multicolumn{3}{|c|}{ Optimal conditions } & \multirow[b]{2}{*}{$\begin{array}{c}\text { Confirmat } \\
\text { ion test } \\
\text { results }\end{array}$} & \multirow[b]{2}{*}{$\begin{array}{l}\text { Predicted } \\
\text { value }\end{array}$} & \multirow[b]{2}{*}{$\begin{array}{l}\text { Confidence } \\
\text { interval } \\
\text { (CI) }\end{array}$} & \multirow[b]{2}{*}{ Differences } & \multirow[b]{2}{*}{ Results } \\
\hline & $\begin{array}{l}\text { Material } \\
\text { type }\end{array}$ & $\begin{array}{c}\text { Sliding } \\
\text { distance }\end{array}$ & $\begin{array}{c}\text { Emery } \\
\text { paper } \\
\text { number }\end{array}$ & & & & & \\
\hline$\mu$ & $\begin{array}{c}\mathrm{PP} / 0.3 \mathrm{G} \\
0\end{array}$ & 100 & 1200 & 0.2716 & 0.27 & \pm 0.0137 & $|+0.0016|$ & $\begin{array}{c}0.0016<0.01 \\
37 \\
\text { successful } \\
0.637<0.917\end{array}$ \\
\hline WV & & & & 3.07 & 2.433 & \pm 0.9176 & $|+0.637|$ & $\begin{array}{c}6 \\
\text { successful }\end{array}$ \\
\hline
\end{tabular}
a 95\% confidence level. Thus, the system optimization for $\mu$ and WR was achieved using the Taguchi method at a significance level of 0.05 .

Table 5. Comparisons the results of confirmation tests and predicted values by the Taguchi method. 


\section{Macro-disc}
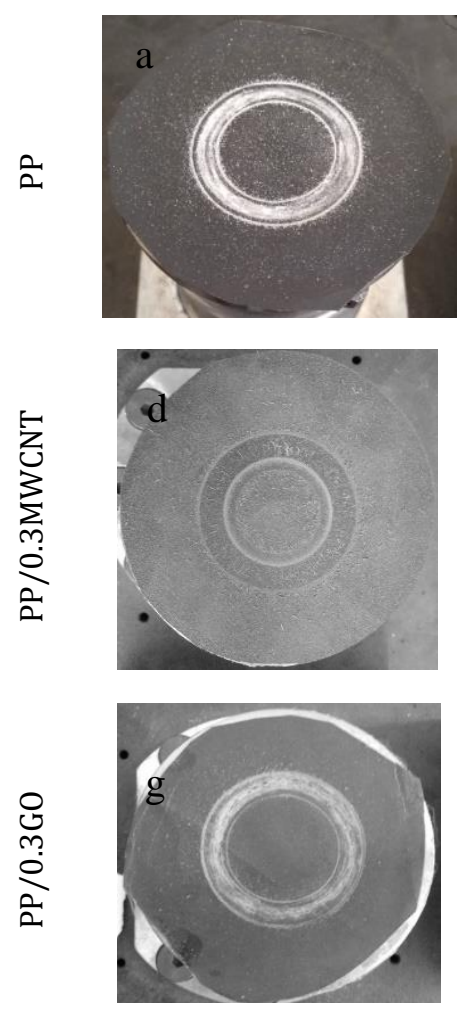

Micro-disc
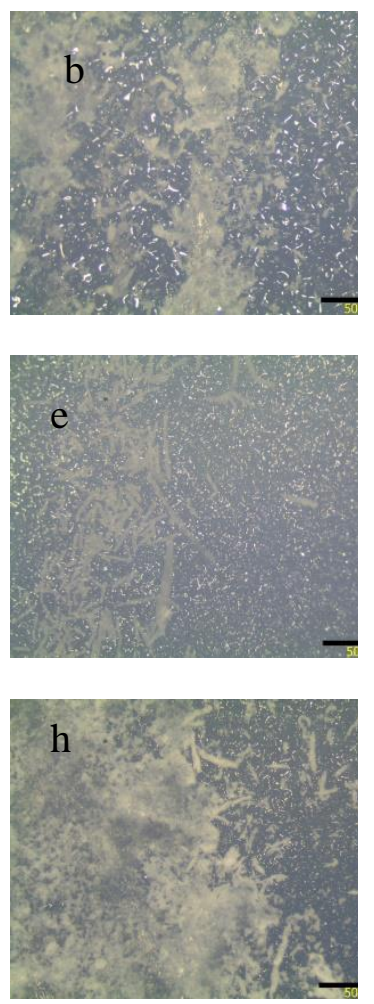

Pin
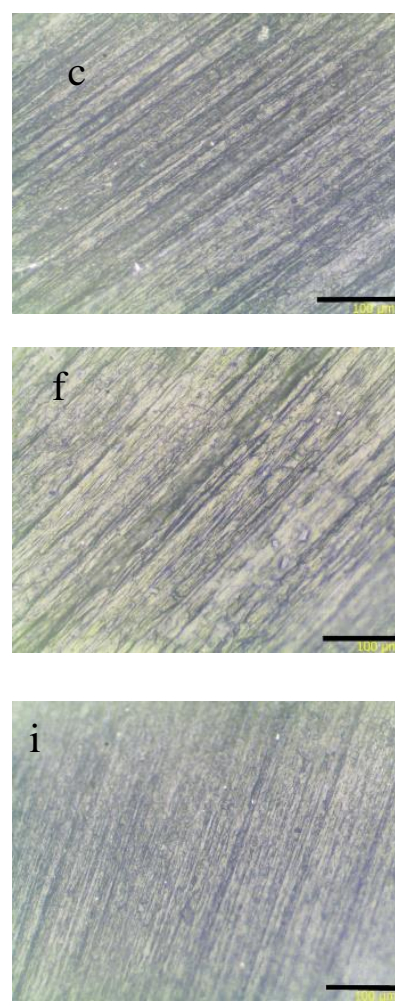

Fig. 6 Optical microscope of worn surfaces of disc and pin surfaces for PP and PP nanocomposites

The macro and micro-optical microscopy examination of the worn disc and pin surfaces of pure PP polymer, PP/0.3GO and PP/0.3MWCNT composites against emery paper with grit grade of 400 and sliding distance of $400 \mathrm{~m}$ is given in Figure $6 \mathrm{a}-1$. It is seen that from the macro and micro disc images, the transfer film layer is formed on the abrasive disc surface. The transfer film layer prevented the contact between the polymer and the disc surface and caused to decrease in the coefficient of friction. For pure PP polymer, the worn surface of the pin showed sliding with wider and deeper grooves due to ploughing action by sharp abrasive particles (Fig $6 \mathrm{c}$ ). A smoother worn pin surface is observed for PP/0.3GO and $\mathrm{PP} / 0.3 \mathrm{MWCNT}$ nanocomposites under the same conditions see Fig $6 \mathrm{f}$ and $\mathrm{l}$. This is explained as the particles are transferred more easily out of the contact area and regions of smooth matrix materials are visible. Therefore, the mechanism is a combination of adhesive and abrasive wears.

\section{Conclusions}

The results of the abrasive wear tests of GO and MWCNT filled PP composites are as follows:

The addition of the GO and MWCNT fillers in the PP polymer increases the WV and $\mu$ of the PP composites. WV and $\mu$ increased with increasing sliding distance, while decreased with increasing emery paper number for all tested materials. The coefficient of friction of the MWCNT and GO filled PP nanocomposites decreased by $19 \%$ and $23 \%$ compared to 
unfilled PP polymer, respectively. GO filled PP nanocomposites was found to be approximately 95\% less wear volume than MWCNT filled PP nanocomposites. The optimal condition for $\mu$ and $\mathrm{WV}$ is the material type at level 3 (PP/0.3GO), the sliding distance at level $1(100 \mathrm{~m})$, and the emery paper number at level $3(1200)$. It can also be concluded that the design factor material type has a major effect on the $\mu$ while sliding distance has a major effect on the WV. The experimental results approved the accuracy of the Taguchi method for enhancing the tribological properties and optimizing the tribological parameters under abrasive conditions. Graphene oxide can be used as an effective modifier to improve the wear performance of PP polymer under harsh tribological conditions.

\section{References}

[1] Mertens AJ, Senthilvelan S. Mechanical and tribological properties of carbon nanotube reinforced polypropylene composites. Journal of Materials: Design and Applications. 2018;232(8):669-680. https://doi.org/10.1177/1464420716642620

[2] Ravi Kumar BN, Suresh B, Venkataramareddy M. Effect of Abrasives on Three-Body Abrasive Wear Behaviour of Particulate-Filled Polyamide66/Polypropylene Nanocomposites. Composite Interfaces. 2010;17:113-126. https://doi.org/10.1163/092764410X490536

[3] Yuanshi X, Fanglin X, Mingming W, Tongsheng L. Synergistic Effects of Carbon Nanotube/Nano-MoS2 Hybrid on Tribological Performance of Polyimide Nanocomposite Films. Tribology Letters. 2018; 66(25):1-18. https://doi.org/10.1007/s11249-017-0977-7

[4] Hassan A. El-Sayed M, EiD A.I, El-Sheikh M, Ali WY. Trıbological propertıes of Low Density Polyethylene and Polyamide 12 as polymer matrix nanocomposites, Journal of the Egyptian Society of Tribology. 2017;14(4):40-53.

[5] Yuanshi X, Tongsheng L, Dafei G, Fanglin X, Mingming W. Preparation and tribological properties of graphene oxide/nano-MoS2 hybrid as multidimensional assembly used in the polyimide nanocomposites. RSC Advances. 2017;7:6323-6335. https://doi.org/10.1039/C6RA27108A

[6] Beibei C, Xiang L, Yuhan J, Lin X, Hongyu L, Xiaofang L, Jin Y, Changsheng L, Fengyuan Y. Fabrication of ternary hybrid of carbon nanotubes/graphene oxide/MoS2 and its enhancement on the tribological properties of epoxy composite coatings. Composites Part A. 2018;115:157-165. https://doi.org/10.1016/i.compositesa.2018.09.021

[7] Barretta R, Ali Faghidian S, Marotti de Sciarra F, Pinnola F. P. Timoshenko nonlocal strain gradient nanobeams: Variational consistency, exact solutions and carbon nanotube Young moduli. Mechanics of Advanced Materials and Structures.2019;1-15. https://doi.org/10.1080/15376494.2019.1683660

[8] Shim YS, Park SJ. Influence of glycidyl methacrylate grafted multiwalled carbon nanotubes on viscoelastic behaviors of polypropylene nanocomposites. Carbon Letters. 2010;11:311-315. https://doi.org/10.5714/CL.2010.11.4.31

[9] Golchin AAW, Nazanin E. An investigation into tribological behaviour of multi-walled carbon nanotube/graphene oxide reinforced UHMWPE in water lubricated contacts. Tribology International. 2016;95:156-161. https://doi.org/10.1016/i.triboint.2015.11.023

[10] Liu Y, Qıhua W, Tingmeı W, Guangqin P. Preparation and tribological properties of graphene oxide/nitrile rubber nanocomposites. Journal of Materials Science.2012;47:730-738. https://doi.org/10.1007/s10853-011-5846-4

[11] Padenko E, Van Rooyen LJ, Wetzel B, Karger-Kocsis J. "Ultralow" sliding wear polytetrafluoro ethylene nanocomposites with functionalized graphene. Journal of Reinforced Plastics and Composites. 2016;1-10. https://doi.org/10.1177/0731684416630817 
[12] Bastiurea M, Dumitru D, Gabriel A. Effect of Graphene Oxide and Graphite on Dry Sliding Wear Behavior of Polyester Composites. Materıle Plastıce. 2018;55(1):102110. https://doi.org/10.37358/MP.18.1.4973

[13] Hassan A. El-Sayed M, Alaa I. EiD, El-Sheikh M, Ali WY. Effect of graphene nanoplatelets and paraffin oil addition on the mechanical and tribological properties of Low-Density Polyethylene nanocomposites. Arabian Journal for Science and Engineering. 2018;43:1435-1443. https://doi.org/10.1007/s13369-017-2965-5

[14] Pan B, Shupeng Z, Wenzhong L, Jing Z, Jinlong L, Yuqing Z, Yongzhen Z. Tribological and mechanical investigation of MC nylon reinforced by modified graphene oxide. Wear. 2012;294-295:395-401. https://doi.org/10.1016/i.wear.2012.07.032

[15] Shen XJ, Xian-Qiang P, Yu L, Shao-Yun F. Tribological performance of carbon nanotubegraphene oxide hybrid/epoxy composites. Composites: Part B. 2014;57:120-125. https://doi.org/10.1016/i.compositesb.2013.09.050

[16] Firojkhan P, Hemant G, Sonam G. Optimization for Tribological Properties of Glass Fiber-Reinforced PTFE Composites with Grey Relational Analysis. Journal of Materials. 2016;1-7. https://doi.org/10.1155/2016/8981746

[17] Sudheer M, Ravikantha P, Raju K, Thirumaleshwara B. Optimization of Dry SlidingWear Performance of Ceramic Whisker Filled Epoxy Composites Using Taguchi Approach. Advanced Tribology. 2012;1-9. https://doi.org/10.1155/2012/431903

[18] Sudeepan J, Kumar K, Barman TK, Sahoo P. Study Of Tribological Properties Of ABS/Kaolin Polymer Composite Using Taguchi Technique. International Journal of Applied Engineering Research. 2014;9(26):8755-8758.

[19] Lawal D, Annas BA, Abdul Samad M. Tribological investigations of carbon nanotubereinforced polymer (UHMWPE) nanocomposites using Taguchi methodology. Journal Applied Polymer Science. 2016;44018-44030. https://doi.org/10.1002/app.44018

[20] Mahapatra SS, Amar P. Study on mechanical and erosion wear behavior of hybrid composites using Taguchi experimental design. Materials and Design. 2009;30:27912801. https://doi.org/10.1016/j.matdes.2009.01.037

[21] Rafiee MA, Lu W, Thomas AV, Zandiatashbar A, Rafiee J, Tour JM, Koratkar NA. Graphene nanoribbon composites. ACS Nano. 2010;4(12):7415-7420. https://doi.org/10.1021/nn102529n

[22] Rafiee MA, Rafiee J, Wang Z, Song H, Yu Z-Z, Koratkar N. Enhanced mechanical properties of nanocomposites at low graphene content. ACS Nano. 2009;3(12):38843890. https://doi.org/10.1021/nn9010472

[23] Padenko E., van Rooyen L.J. and Karger-Kocsis J. Transfer Film Formation in PTFE/Oxyfluorinated Graphene Nanocomposites During Dry Sliding. Tribology Letters. 2017; (65):36-47. https://doi.org/10.1007/s11249-017-0821-0

[24] An Y., Zhixin T., Yuanyuan Q., Xingbin Y., Bin L., Qunji X. and Jinying P. Friction and Wear Properties of Graphene Oxide/Ultrahigh-MolecularWeight Polyethylene Composites Under the Lubrication of Deionized Water and Normal Saline Solution. Journal Applied Polymer Science. 2014;39640-39651.

[25] Deprez P, Hivart P, Coutouly JF, Debarre E. Friction and wear studies using taguchi method: application to the characterization of carbon-silicon carbide tribological couples of automotive water pump seals. Advances in Materials Science and Engineering. 2009:1-10. https://doi.org/10.1155/2009/830476

[26] Suresha B, Kunigal N, Shiva K. Investigations on mechanical and two-body abrasive wear behaviour of glass/carbon fabric reinforced vinyl ester composites. Materials and Design. 2009;30:2056-2060. https://doi.org/10.1016/j.matdes.2008.08.038

[27] Ross PJ. Taguchi Techniques for Quality Engineering, McGraw-Hill Education (India) Pvt Limited, 2005. ISBN 0070598800.

[28] Kacal A. Determination of optimal cutting conditions in finish turning of austempered ductile iron using Taguchi design method, Journal of Scientific \& Industrial Research. 2011;70:278-283. 
[29] Roy RK. A Primer on the Taguchi Method. Competitive Manufacturing Series, 1st ed., Van Nostrand Reinhold; 1990. 